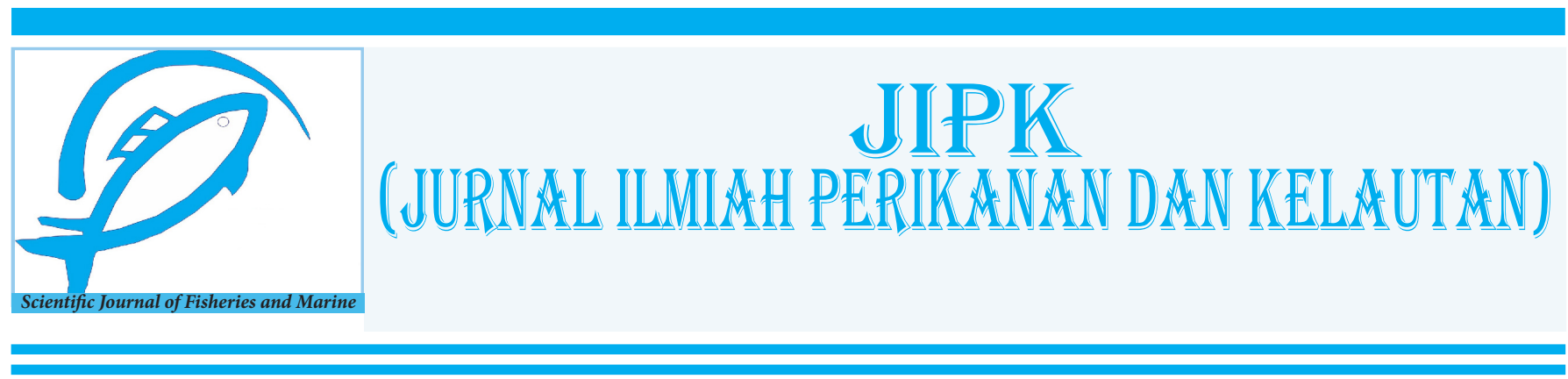

Research Article

\title{
The sustainability of Saltworks Integration in Pati Regency, Central Java
}

\author{
Sriwati $^{1 *}$ (D), Azis Nur Bambang ${ }^{2}$ Johannes Hutabarat $^{2}$, Haeruddin $^{2}$, and Tri Winarni Agustini ${ }^{2}$ \\ ${ }^{1}$ Doctoral Student in Coastal Resources Management, Faculty of Fisheries and Marine Science, Diponegoro University, Semarang, Central \\ Java, 50275. Indonesia \\ ${ }^{2}$ Department of Fisheries, Faculty of Fisheries and Marine Science, Diponegoro University, Semarang, Central Java, 50275. Indonesia
}

\section{OPEN ACCESS}

\section{ARTICLE INFO}

Received: January 04, 2022

Accepted: January 30, 2022

Published: February 05, 2022

*) Corresponding author:

E-mail: sriwatisriwati32@gmail. com

\section{Keywords:}

Sustainability

Integration

ETESI Aspects

Rapfish

This is an open access article under the CC BY-NC-SA license (https://creativecommons.org/ licenses/by-nc-sa/4.0/)

\begin{abstract}
Saltworks integration is one of the government's efforts as a breakthrough in saltworks technology innovation. Saltworks integration in Pati Regency has been conducted for 4 (four) years starting from 2017 to 2020. The aim of this research was to analyze the sustainability of saltworks integration in terms of ecological, technological, economic, social, and institutional (ETESI) aspects. The research was conducted for 9 (nine) months from March to November 2020. The research locations for saltworks integration were in Raci Village - Batangan Subdistrict, Genengmulyo Village - Juwana Subdistrict, Tluwuk Village - Wedarijaksa Subdistrict, and Kertomulyo Village - Trangkil Subdistrict. Sustainability analysis was performed using Rapfish method. Through the R software, the anchor was created automatically so that users only need to input data through Microsoft Excel, then the Rapfish analysis was carried out automatically by the R software. The results of the sustainability index analysis of saltworks integration in the ecological aspects of Raci Village, Batangan Subdistrict showed a sustainable index value. Genengmulyo Village - Juwana Subdistrict, Tluwuk Village - Wedarijaksa Subdistrict, and Kertomulyo Village Trangkil Subdistrict had an opportunity of attaining sufficiently sustainable status by considering indicators that affect its sustainability. Technological, economic, social and institutional aspects in all villages, where saltworks integration was located, showed a sufficiently sustainable status.
\end{abstract}

Cite this as: Sriwati, Bambang, A. N., Hutabarat, J., Haeruddin, \& Agustini, T. W. (2022). The sustainability of Saltworks In tegration in Pati Regency, Central Java. Jurnal Ilmiah Perikanan dan Kelautan, 14(1):105-117. http://doi.org/10.20473/jipk. v14i1.32553 


\section{Introduction}

Sustainability is a part of a process in anactivity and sustainability is an effort to carry out strategies for human-nature relations (Kopnina, 2017). Saltworks activity is an activity that continues to exist and is very much integrated in the community. Salt are goods that do not have a substitute (substitution goods), thus the demand is continuous. Different from the programs / activities in saltworks activities which are always changing, changes in programs and policies of saltworks depend on the leadership in an agency / institution (Nayar et al., 2019). One of the new activities in the saltworks activity is the saltworks integration. Saltworks integration is a part of Community Salt Business Development activities called Pengembangan Usaha Garam (PuGar). Saltworks integration is the unification of the place and process of salt production in a unified expanse of land with a minimum limit of 15 (fifteen) Ha (Ministry of Marine Affairs and Fisheries, 2020). Saltworks integration activities is to improve the welfare of salt farmers (Fernandes et al., 2020; Muhandhis et al., 2021). The success of saltworks integration through an approach for increasing productivity, quality, continuity, and business institutions (corporatization).

Pati Regency is one of the Regencies that has carried out saltworks integration activities since 2017. It is hoped that in the future Pati Regency can become a salt city. Saltworks integration has positive and negative impacts. Saltworks integration has advantages regarding environmental sustainability (Soares et al., 2018). Salinity conditions in saltworks also have an impact on biology and pond conditions (Ladhar et al., 2015), biodiversity and human sustainability. Sustainability of salt production is determined by physical and biological factors, in which physical factors are affected by seawater evaporation which is influenced by weather, while biological factors are supported by the presence of various organisms (Vieira and Bio, 2011). The low level of technological innovation and environmental integration can affect the sustainability of quality salt production, i.e., the process of water conditions (Liyanaarachchi et al., 2014), management relationship on the physical condition of ponds and humans (Rocha et al., 2012). The sustainability is also supported by the existence of seawater basins as the first step before being distributed in salt pond basins (Rodrigues et al., 2011) and management of distribution irrigation soil conditions
(González-Alcaraz et al., 2015). The utilization of water can be used as a consideration of economic and environmental sustainability indicators (Sainz-López, 2017). Saltworks activity is a business that has risks (Sudaryana and Pramesti, 2018). The factors that influence salt production, among others, are the uncertain climate (Costa et al.,2015) and there is no guarantee of the price of salt. Salt farmers are people who are affected by erratic saltworks activity. The government and other stakeholders are trying to be present to solve this problem because the salt policy is a macro policy that requires treatment from several related agencies (Suhendi et al., 2020).

Saltworks integration is one of the government's efforts as a breakthrough in saltworks technology innovation. The saltworks integration activity is one of the processes of the PuGar program that must be reviewed for its sustainability. A sustainability strategy for saltworks integration is required for program achievements. Saltworks integration in Pati Regency has been running for 4 (four) years, and the level of sustainability of saltworks integration needs to be examined. The dimensions of sustainability include ecology, economy, socio-culture, technology, and institutions in order to achieve sustainable salt exploitation (Ariyani et al., 2020). The existence of technology with a hybrid system can be applied as a sustainable management of salt water desalination (Panagopoulos, 2020). Climate change can also affect the sustainability of farmers' salt production (Kurniawan and Zulham, 2020). Ecologically, ponds can be beneficial for small fish and crustaceans, Artemia (Nguyen et al., 2020). Sustainability of saltworks integration in the technological aspect by placing the location of saltworks integration close to the sea and the distance from the beach not exceeding $3,000 \mathrm{~m}$, in accordance with the statement of the technical guidelines for saltworks integration implementation with the assistance of Field Fisheries Extension (FFE), Auxiliary Fisheries Extension (AFE) so that the salt quality can meet industrial salt standard according to SNI 4435:2017. Other studies have also revealed that the distance between the glass and the surface of the water can facilitate evaporation and easy removal of salts that have deposited with water that overflows from a sloping surface (Patel et al., 2019). The sustainability of saltworks integration is an effort to study and assess 
the continuity of the salt business in terms of several aspects. Sustainability aspects include ecological, technological, economic, social, and institutional (ETESI) aspects. This sustainability analysis is presented in a sustainability index which reflects the status of the sustainability of the program implementation based on current conditions. These aspects were studied so that the impacts on the sustainability of saltworks integration are determined. The aim of the research is to analyze the sustainability of saltworks integration in terms of ecological, technological, economic, social, and institutional (ETESI) aspects.

\section{Materials and Methods}

\subsection{Description of the Study Sites}

This research was conducted in Pati Regency, Indonesia, with a productive salt land area of 2,901.62 Ha. The area of productive salt land in Pati Regency is spread over 4 (four) Subdistricts which are concentrated in 21 villages. The location of the saltworks integration includes Raci Village - Batangan Subdistrict, Genengmulyo Village - Juwana Subdistrict, Tluwuk Village - Wedarijaksa Subdistrict, and Kertomulyo Village - Trangkil Subdistrict. The total area of the integrated saltworks area was 293.59 hectares. The total area of the sample for integration land was $72,54 \mathrm{Ha}$ or $(25 \%)$ of the area of saltworks integration in Pati Regency.

\subsection{The Research Material}

The research material used was primary data and secondary data. Primary data was obtained from direct observations in the field. Secondary data was data obtained indirectly by study of the literature, books and documents from related agencies. Relevant agencies include the Marine and Fisheries Service, Industry and Trade Service, Development Planning Agency at Sub-National Level (Bappeda), Statistics Agency, Meteorology, Climatology, and Geophysical Agency (BMKG) and other agencies. The research was conducted for 9 (nine) months from March to November 2020.

\subsection{Aspects of the Sustainability Indicators of Salt- works Integration}

Ecological aspects included the type of pond soil for the integration of saltworks, water temperature in the pond for the saltworks integration production process, the degree of baume $(\mathrm{Be})$ for the reservoir ( $\mathrm{em}$ bung) location, the degree of baume $(\mathrm{Be})$ for the seeding location, the degree of baume $(\mathrm{Be})$ for the location of the crystallization, long exposure to sunlight for the saltworks integration production process, rainfall inten- sity for saltworks integration activities, wind speed for the saltworks integration production process.

Economic aspects included salt productivity from saltworks integration, saltworks integration production process costs, availability of capital for salt farmers (land owners), leasing costs for pond land of saltworks integration, transportation costs from ponds to roads / warehouses, average income of saltworks integration salt farmers, average income increase of saltworks integration salt farmers, difference in traditional salt prices and saltworks integration salt prices, labor efficiency in the saltworks integration area.

Social aspects included potential conflicts between saltworks integration farmers and traditional farmers, potential internal conflicts of saltworks integration farmers, profit sharing systems for salt farmers (cultivators) and fish/salt pond owners, number of recipients (people who benefit from saltworks integration support) in 1 (one) group, the length of domicile of salt farmers, experience of salt farmers in the salt production process, the influence of the salt cooperatives existence for the SRG system management, the influence of the group existence for the salt production management, the influence of the middlemen existence for the salt production management, the influence of the SMIs existence for the salt processing, the influence of the policy on the import of salt.

Technological aspects included the main embankment height of the pond for saltworks integration, the width of the pond galleys for saltworks integration, the size of the crystallization table, the water height on the crystallization table, the distance between the sea and land of saltworks integration, the harvesting period/ the appropriate collection process for the results of saltworks integration, the $\mathrm{NaCl}$ content (adbk) of the salt resulted from the saltworks integration.

Indicators for the sustainability of saltworks integration in institutional aspects include the number of socialization and assistance from the Ministry of Marine Affairs and Fisheries for salt farmers receiving saltworks integration, the number of group members to hold meetings to support the good implementation of saltworks integration, the number of managers for the production process at the crystallization table, the number of salt buyers / traders of the saltworks integration, the influence of the salt cooperatives existence for the SRG system management, the influence of the Village Owned Enterprises existence for salt production management, the influence of the groups existence for salt production management, the influence of the mid- 
dlemen existence for post-production management, the influence of the Small and Medium Industry (SMIs) existence for salt processing, the influence of the policy of salt import. The index and sustainability status are categorized from poor to good (Table 1). The review of the sustainability of saltworks integration in the ETESI aspects is based on the value / score of each indicator and sub-indicator so that it shows a picture of the sustainability of salt integration.

\subsection{Data Analysis}

Implementation of a sustainability analysis was performed using Rapfish method. Through the R software platform, the anchor was created automatically, so that users only need to input data through Microsoft Excel, then the Rapfish analysis was carried out automatically by the R software. Rapfish software was designed to assess the sustainability status of a system on a poor to good scale. The tipping point on Rapfish is the attribute chosen to rank on a particular dimension.

Table 1. Index and Status of Sustainability

\begin{tabular}{ll}
\hline Index Value & Category \\
\hline $00.00-25.00$ & Poor: Not sustainable \\
$25.01-50.00$ & Less: Less sustainable \\
$50.01-75.00$ & Sufficient: Sufficiently sustainable \\
$75.01-100.00$ & Good: Very sustainable \\
\hline
\end{tabular}

source: Kavanagh and Pitcher (2004)

\section{Results and Discussion}

\subsection{Sustainability of Saltworks Integration in Eco- logical Aspects}

The value of the saltworks integration sustainability index in the ecological aspects shows the value of the saltworks integration sustainability index in the ecological aspects (Figure 1). For Raci Village - Batangan Subdistrict, the value of the sustainability index was 77.79 with the status of sustainable saltworks integration because the index value was $>75$. Genengmulyo Village - Juwana Subdistrict had a sustainability index value of 65.62. Tluwuk Village - Wedarijaksa Subdistrict had a sustainability index value of 58.24. Kertomulyo Village - Trangkil Subdistrict had a sustainability index value of 72.01. Genengmulyo Village - Juwana Subdistrict, Tluwuk Village - Wedarijaksa Subdistrict, Kertomulyo Village - Trangkil Subdistrict had a sufficiently sustainable status with an index value of 50 - 74.9. Based on the ecological aspect, Raci Village Batangan Subdistrict has the opportunity for sustainable saltworks integration. Genengmulyo Village - Juwana
Subdistrict, Tluwuk Village - Wedarijaksa Subdistrict, and Kertomulyo Village - Trangkil Subdistrict had an opportunity of sufficiently sustainable by considering the indicators that affect its sustainability.
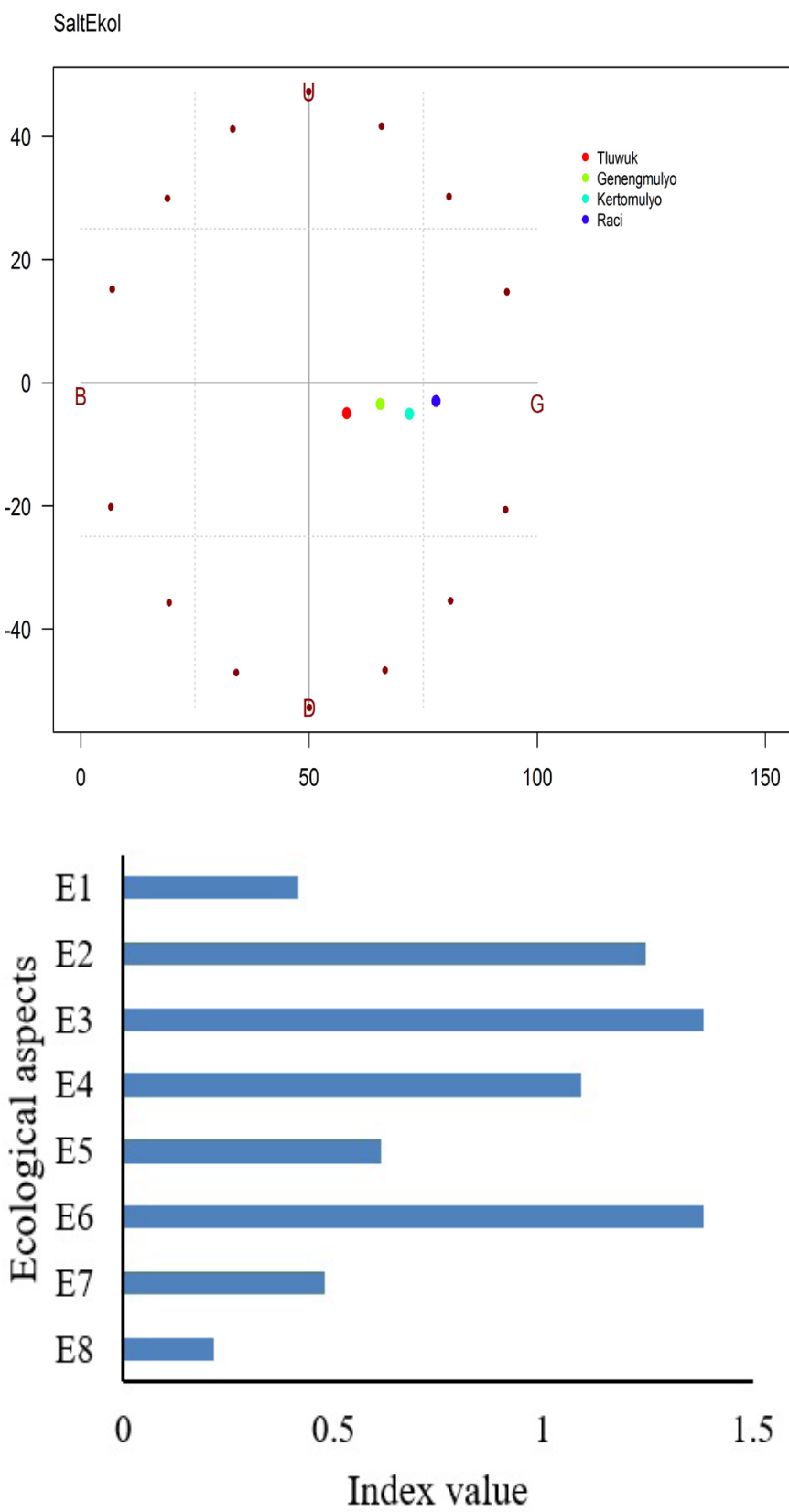

Figure 1. Sustainability Index Value and Leverage Analysis of Saltworks Integration in Ecological Aspects.

Note: E1 = wind speed, E2 = rainfall intensity, E3 = long exposure to sunlight, $\mathrm{E} 4=$ degree of baume $(\mathrm{Be})$ for the location of the crystallization, E5 = the degree of baume (Be) for the seeding location, E6 = the degree of baume $(\mathrm{Be})$ for the reservoir (embung) location, E7 = water temperature, E8 $=$ type of pond soil 
JIPK. Volume 14 No 1. April 2022 / The sustainability of Saltworks Integration in Pati Regency, Central Java.

Leverage analysis in ecological aspects affects the sustainability of saltworks integration. The highest Leverage analysis value was on 3 (three indicators) as follows the duration of sun exposure for the saltworks integration production process with a Leverage value of 1.38, the degree of baume $(\mathrm{Be})$ for the reservoir location with a Leverage value of 1.37 , and rainfall intensity for saltworks integration activities with a Leverage value of 1.24. The duration of irradiation and rainfall affected the process of evaporation of seawater into crystallization of salt. The longer the sun is exposed, the evaporation process is faster, and the more crystallization of salt settles. Salt production is heavily influenced by the weather (Jiang et al., 2019). The degree of baume (Be) at the reservoir location is the starting point for the $\mathrm{Be}$ content at the seeding site and the crystallization table. In the integrated production process, the water is flowed through FTT (Filter Thread Technology). The higher the Be content entered at the reservoir location results in the greater percentage of salt $(\mathrm{NaCl})$ content on the crystallization table (Nariyoshi et al., 2016; Misyura, 2020). The $\mathrm{NaCl}$ content in the salt depends on the location where the sea water was taken (Geng et al., 2016; Jiang et al., 2019). The increase in temperature can affect the phenomenon of salt farmers, so farmers must have adaptation strategies (Kurniawan and Zulham, 2020).

\subsection{Sustainability of Saltworks Integration in Tech- nological Aspects}

The sustainability index analysis of the saltworks integration and the Leverage analysis in the technological aspects were analyzed using the Rapfish analysis of R program (Figure 2). Raci Village - Batangan Subdistrict had a sustainability index value of 74.36. Genengmulyo Village - Juwana Subdistrict had a sustainability index value of 57.84. Tluwuk Village - Wedarijaksa Subdistrict had a sustainability index value of 54.36. Kertomulyo Village - Trangkil Subistrict had a sustainability index value of 74.95 . The value of the saltworks integration sustainability index in the technology aspects shows that all saltworks integration villages were sufficiently sustainable with an index value of 50 - 74.9 .

Leverage analysis on the technological aspect affected the sustainability of the saltworks integration. The Leverage analysis in the technological aspect showed the highest value on 3 (three) indicators, including the difference in the distance between the sea and land of saltworks integration with a Leverage value of 2.68. The closer sea distance to the saltworks integration area results in better salt quality. The suitable distance between saltworks integration and the sea was $<3,000$ $\mathrm{m}$. This is in agreement with the statements of Auliyah and Latjolai (2019) that the distance of saltworks land from the sea / coast of $300-1000 \mathrm{~m}$ shows a very suitable indicator.
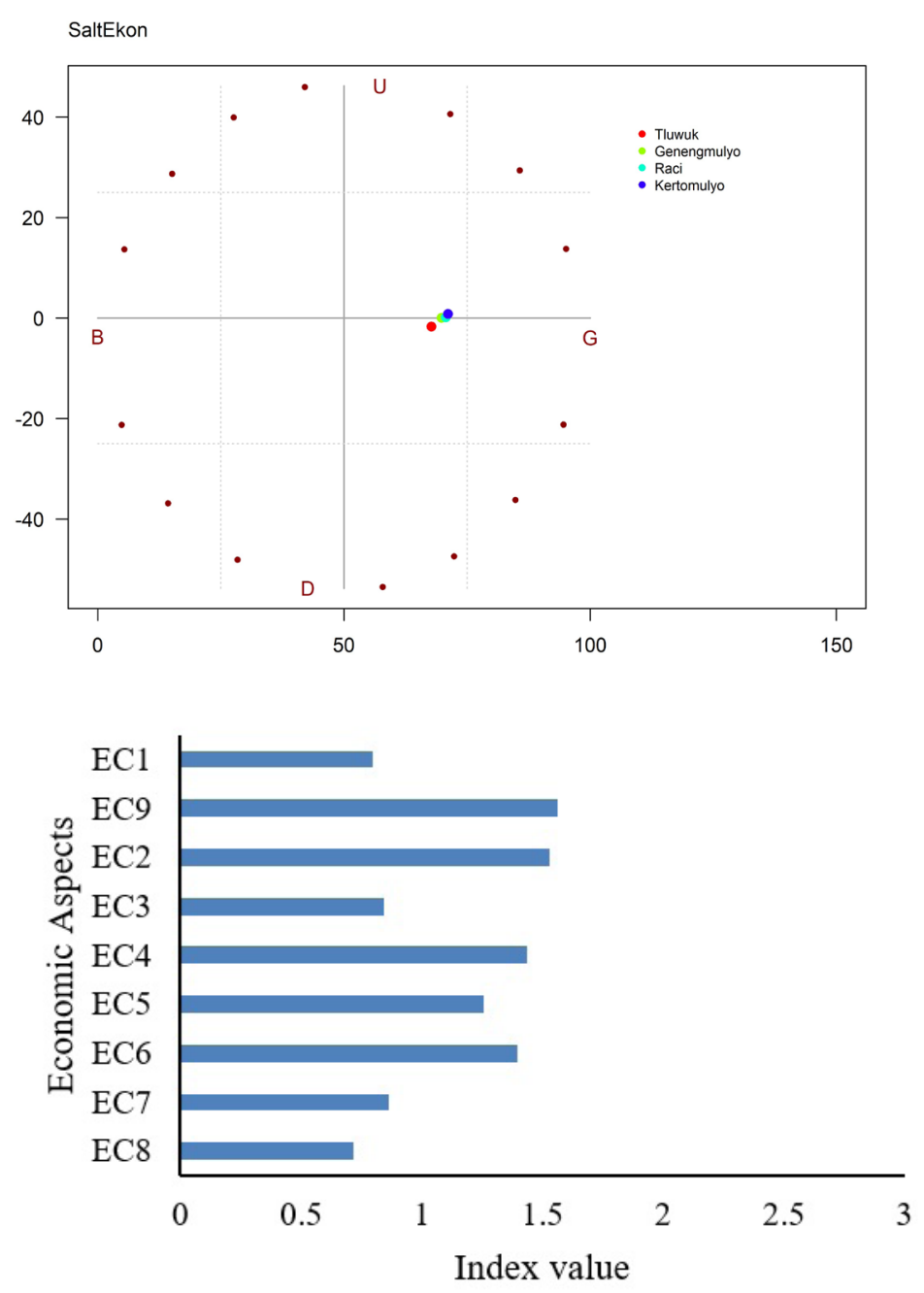

Figure 2. Sustainability Index Value and Leverage Analysis of Saltworks Integration in Economic Aspects. Note: EC1 = Labor efficiency in the saltworks integration area, EC2 = average income increase of saltworks integration salt farmers, EC3 = average income of saltworks integration salt farmers, EC4 = availability of capital for salt farmers (land owners), EC5 = transportation costs from ponds to roads / warehouses, EC6 = leasing costs for pond land of saltworks integration, EC7 $=$ Saltworks integration production process costs, EC $8=$ Salt productivity from saltworks integration, $\mathrm{EC} 9=$ difference in traditional salt prices and saltworks integration salt prices.

Crystallization table size had a Leverage value of 2.48. The crystallization table affected the amount of salt production. The smaller area of saltworks integration results in smaller production. The larger area of saltworks integration results in greater amount of saltworks integration production. The size of the crystallization table affected labor efficiency. The ideal area of 
the crystallization table in the saltworks integration area was $8 \times 42 \mathrm{~m}$. The suitability of the geoisolator size is one of the factors determining the area of the crystallization table area. Water level on the crystallization table had a Leverage value of 1.82. The Greenhouse Salt Tunnel (GST) Method and Technology can be used in the sea salt production (Kurniawan et al., 2019). The existence of further purification can be used as the main foundation in the utilization of seawater sources (Zhang et al., 2021). Utilization of salt water for salt production in wind-driven seawater greenhouses has been reported (Akinaga et al., 2018).
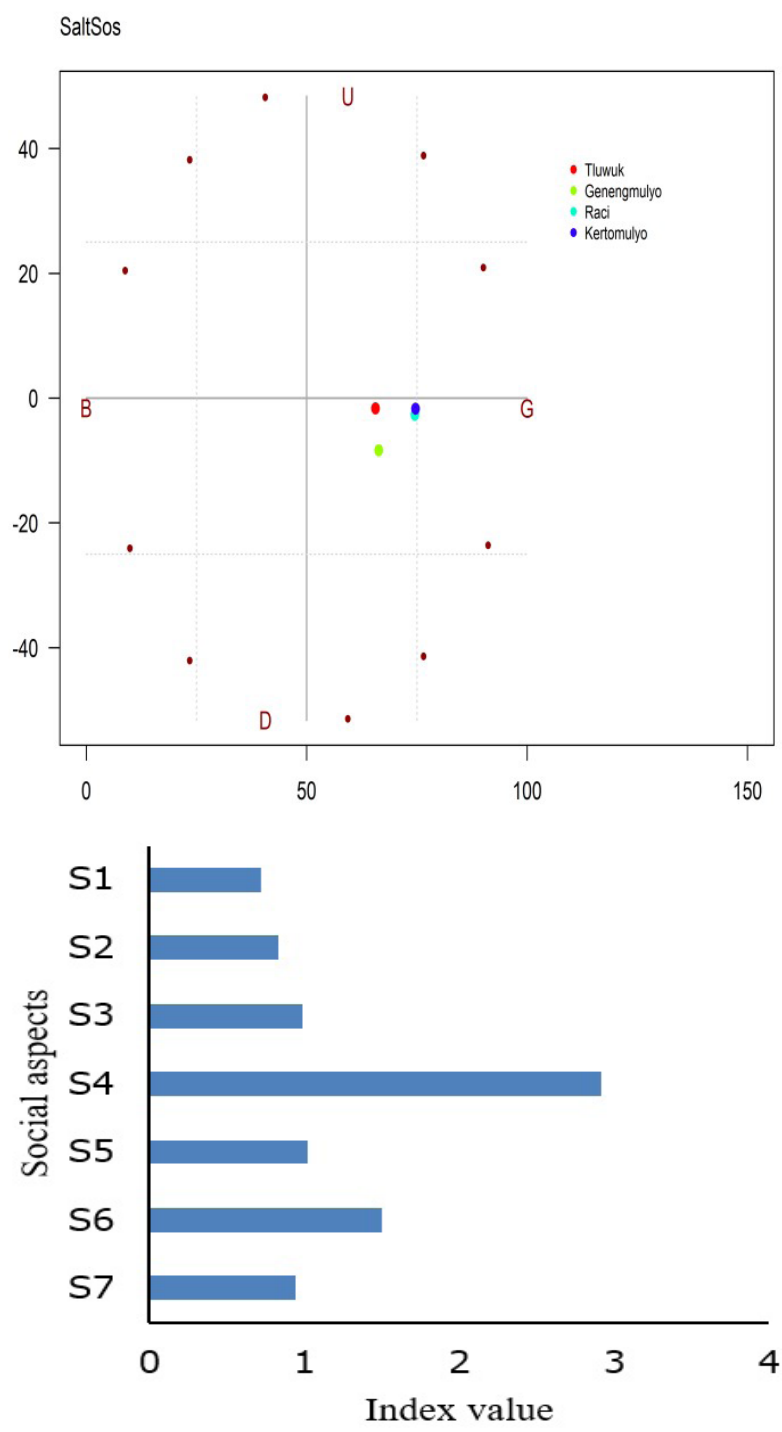

Figure 3. Sustainability Index Value and Leverage Analysis of Saltworks Integration in Social Aspects.

Note: $\mathrm{S} 1=$ Human resources quality, $\mathrm{S} 2=$ experience of salt farmers in the salt production process, $\mathrm{S} 3=$ the length of domicile of salt farmers, $\mathrm{S} 4=$ number of recipients (people who benefit from saltworks integration support) in 1 (one) group, $\mathrm{S} 5=$ Profit sharing systems for salt farmers (cultivators) and fish/salt pond owners, S6 = Potential internal conflicts of saltworks integration farmers, S7 $=$ Potential conflicts between saltworks integration farmers and traditional farmers

\subsection{Sustainability of Saltworks Integration in Eco- nomic Aspects}

The sustainability index analysis of the saltworks integration and the Leverage analysis in the economic aspects were analyzed using the Rapfish analysis of $R$ program (Figure 3). The value of the sustainability index of the saltworks integration in the economic aspects of Raci Village - Batangan Subdistrict with a sustainability index value of 70.65 (Figure 3). Genengmulyo Village - Juwana Subdistrict had a sustainability index value of 69.80. Tluwuk Village - Wedarijaksa Subdistrict had a sustainability index value of 67.73. Kertomulyo Village - Trangkil Subdistrict had a sustainability index value of 71.12. The value of the saltworks integration sustainability index in the economic aspects shows that all saltworks integration villages had a sufficiently sustainable status with an index value of 50 - 74.9. Based on the economic aspects of Raci Village - Batangan Subdistrict, Genengmulyo Village - Juwana Subdistrict, Tluwuk Village - Wedarijaksa Subdistrict, Kertomulyo Village - Trangkil Subdistrict showed a sufficiently sustainable status by considering the indicators that influence its sustainability.

Leverage analysis on the economic aspect affected the sustainability of the saltworks integration. The value of Leverage analysis in of economic aspects showed the highest value on 3 (three) indicators, including the difference in traditional salt prices and saltworks integration salt prices with a Leverage value of 1.56 , availability of capital for salt farmers (land owners) with a Leverage value of 1.44 , and leasing costs for pond land of saltworks integration with a Leverage value of 1.34 .

Price is the main indicator for the sustainability of the saltworks integration in economic aspects. The good quality of salts resulting from saltworks integration with high $\mathrm{NaCl}$ if not balanced with a good price greatly affected the sustainability of the saltworks integration program. Salt farmers hoped that there will be differences in the price of salt from the saltworks integration compared to the traditional salt. Efforts to improve quality are meaningless if they are not considered by price differences. Prior to saltworks integration, the price of traditional farmer's salt was determined by the middlemen. The availability of capital for salt farmers (land owners) is an indicator of the sustainability of saltworks integration in the economic aspects. Partnerships have an effective role in improving the economy of salt farmers, i.e., wholesalers as managers, shipping cooperatives, and salt farmers as salt producers (Fatmawati and Kurdi, 2020). Economic development of 

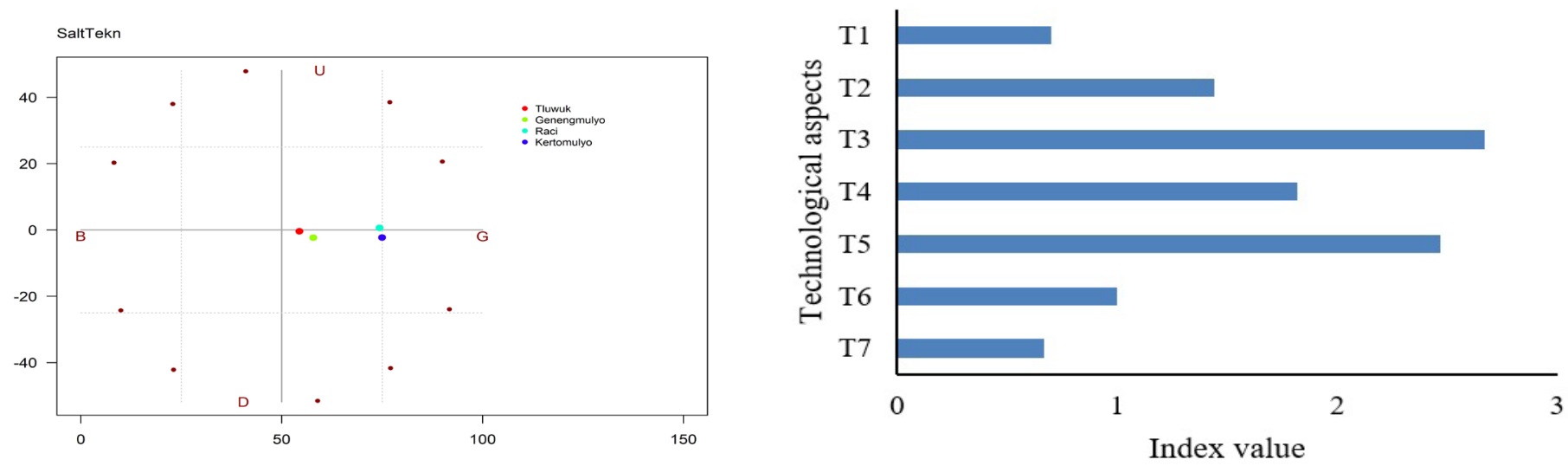

Figure 4. Sustainability Index Value and Leverage Analysis of Saltworks Integration in Technological Aspects. Note: $\mathrm{T} 1=$ the $\mathrm{NaCl}$ content (adbk) of the salt, $\mathrm{T} 2=$ the harvesting period/the appropriate collection process, $\mathrm{T} 3=$ the distance between the sea and land of saltworks integration, $\mathrm{T} 4=$ the water height on the crystallization table, $\mathrm{T} 5=$ the size of the crystallization table, T6 = the width of the pond galleys for saltworks integration, $\mathrm{T} 7$ = height of the pond for saltworks integration
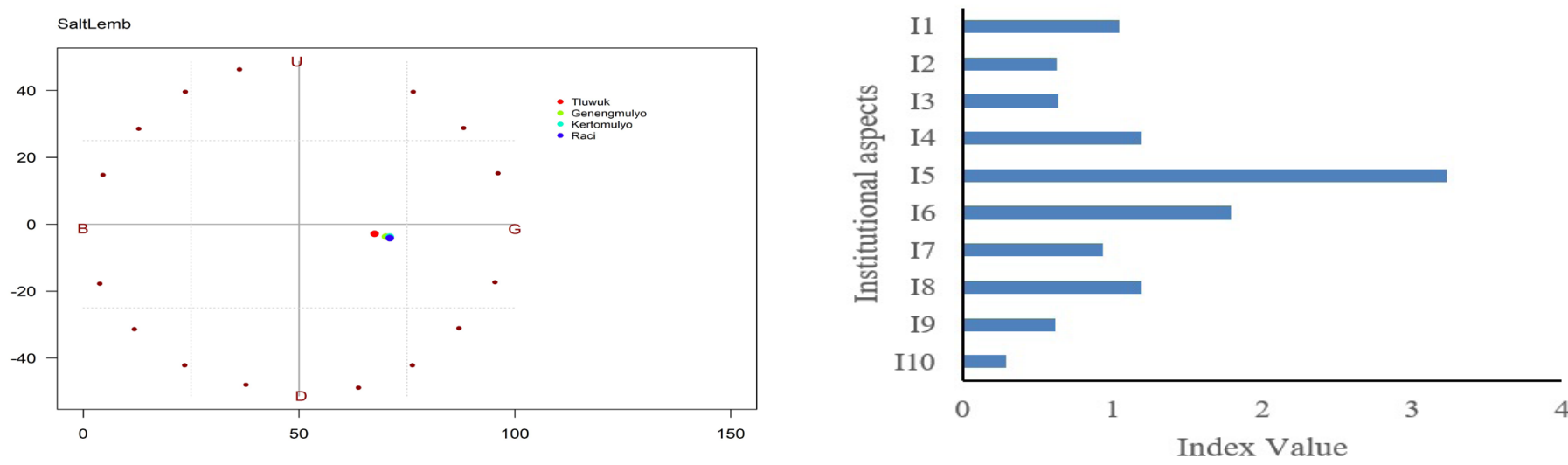

Figure 5. Sustainability Index Value and Leverage Analysis of Saltworks Integration in Institutional. Note: I1 $=$ the influence of the policy of salt import, I2 = the influence of the Small and Medium Industry (SMIs) existence for salt processing, I3 = the influence of the middlemen existence for post-production management, I4 = the influence of the groups existence for salt production management, I5 = The influence of the Village Owned Enterprises existence for salt production management, I6 = The influence of the salt cooperatives existence for the SRG system management, I7 = the number of salt buyers / traders of the saltworks integration, $18=$ the number of managers for the production process at the crystallization table, I9 = the number of group members to hold meetings to support the good implementation of saltworks integration, I10= the number of socialization and assistance

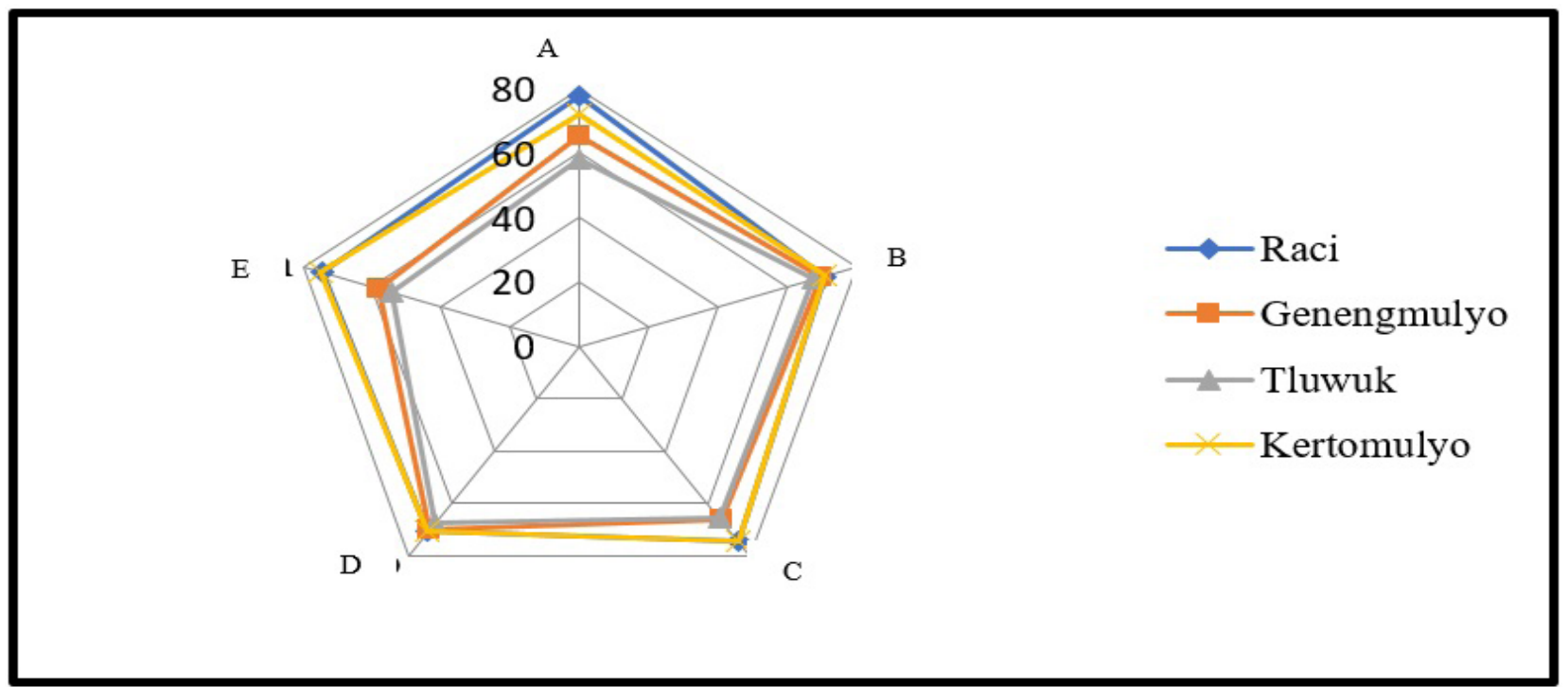

Figure 7. Kite (Radar) Diagram of Saltworks Integration Sustainability (A: salt of ecology, B: salt of economy, C: Salt of social, D: Salt of institution, E: Salt of technology) 
salt farmers can be achieved with support in the creation of cooperatives with guidance support, advocacy, and technological facilities as well as business capital (Rochwulaningsih, 2018). The government, in the saltworks integration program, only provides facilities for saltworks integration, while capital is the responsibility of the salt farmers. Salt farmers were faced with the availability of capital at the beginning of salt production. The cost of leasing pond land for saltworks integration is one indicator of the sustainability of saltworks integration. The economic feasibility of the salt production process is influenced by the market value (Sparenberg et al., 2020). The economic improvement of salt farmers can be performed through productivity improvement programs with optimal technology (Muhandhis et al., 2019).

\subsection{Sustainability of saltworks integration in so- cial aspects}

The sustainability index analysis of the saltworks integration and the Leverage analysis in the social aspects were analyzed using the Rapfish analysis of R program (Figure 4). Raci Village - Batangan Subdistrict had a sustainability index value of 74.54. Genengmulyo Village - Juwana Subdistrict had a sustainability index value of 66.34. Tluwuk Village - Wedarijaksa Subdistrict had a sustainability index value of 65.62. Kertomulyo Village - Trangkil District had a sustainability index value of 74.69 (Figure 4). The value of the saltworks integration sustainability index on the social aspects shows that all saltworks integration villages had a sufficiently sustainable status with an index value of 50 - 74.9 .

Leverage analysis in social aspects affected the sustainability of saltworks integration. Indicators of sustainability of saltworks integration in social aspects include potential conflicts between saltworks integration farmers and traditional farmers, potential internal conflicts of saltworks integration farmers, profit sharing systems for salt farmers (cultivators) and fish/salt pond owners, number of recipients (people who benefit from saltworks integration support) in 1 (one) group, the length of domicile of salt farmers, experience of salt farmers in the salt production process, the influence of the salt cooperatives existence for the SRG system management, the influence of the group existence for the salt production management, the influence of the middlemen existence for the salt production management, the influence of the SMIs existence for the salt processing, the influence of the policy on the import of salt.

The value of Leverage analysis in the social as- pects showed the highest value on 3 (three) indicators, including the number of recipients (people who take advantage of saltworks integration support) in 1 (one) group with a Leverage value of 2.92, potential internal conflicts of saltworks integration farmers with a Leverage value of 1.50 , and profit sharing systems for salt farmers (cultivators) and fish/salt pond owners with a Leverage value of 1.44. The number of recipients (people who take advantage of saltworks integration support) in 1 (one) group is one indicator of the sustainability of the saltworks integration. Equitable distribution of support and right on target is the expected output to improve the welfare of salt farmers. Saltworks integration conflicts often arise during pre, process and post production. Internal conflicts usually occur during land conversion and profit sharing of salt production (Nhung et al., 2019).

\subsection{Sustainability of Saltworks Integration in Insti- tutional Aspects}

The sustainability index analysis of the saltworks integration and the Leverage analysis in the institutional aspects were analyzed using the Rapfish analysis of R program (Figure 5). Raci Village - Batangan Subdistrict had a sustainability index value of 71.04. Genengmulyo Village - Juwana Subdistrict had a sustainability index value of 70.16. Tluwuk Village - Wedarijaksa Subdistrict had a sustainability index value of 67.50. Kertomulyo Village - Trangkil Subdistrict had a sustainability index value of 71.02 (Figure 5). The value of the saltworks integration sustainability index in the institutional aspect showed that all saltworks integration villages had a sufficiently sustainable status with an index value of 50 - 74.9.

Leverage analysis in institutional aspects affected the sustainability of saltworks integration. The value of Leverage analysis in the institutional aspects showed the highest value on 3 (three) indicators, including the influence of the Village Owned Enterprises existence for salt production management with a Leverage value of 3.23, the influence of the salt cooperatives existence for the SRG system management with a Leverage value of 1.79, and the influence of the groups existence for salt production management with a Leverage value of 1.20. The existence of Village Owned Enterprises is expected to be able to move the village economy with the ultimate goal of increasing the welfare of the community. In accordance with the PuGar Technical Guidance, 2019 Pugar recipients are Cooperatives / Village Owned Enterprises in accordance with Law number 32 of 2004 concerning Regional Government "the rights, authorities and obligations of autonomous regions to regulate 
JIPK. Volume 14 No 1. April 2022 / The sustainability of Saltworks Integration in Pati Regency, Central Java.
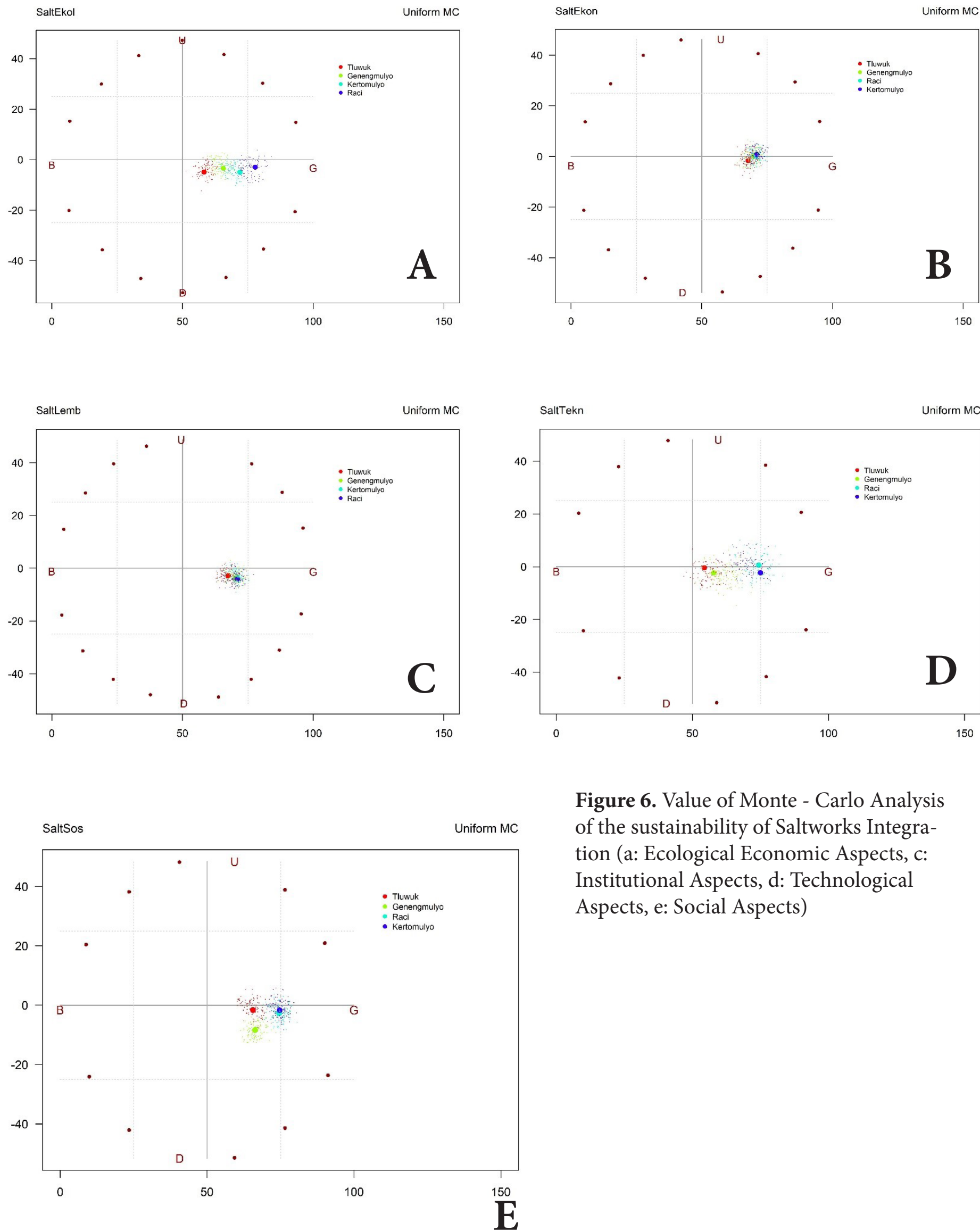

Figure 6. Value of Monte - Carlo Analysis of the sustainability of Saltworks Integration (a: Ecological Economic Aspects, c: Institutional Aspects, d: Technological Aspects, e: Social Aspects) 
and manage government affairs and the interests of local communities in accordance with statutory regulations". Institutionally, Village Owned Enterprises is located in the location of economic activities, adequate quality of human resources, management and members in one village, so that it facilitates coordination and adequate infrastructure because it is near the Village hall. The existence of Village Owned Enterprises is an important indicator in influencing the sustainability of saltworks integration in the institutional aspects.

The influence of the salt cooperatives existence for the SRG system management is an indicator of the sustainability of saltworks integration secondly after the Village Owned Enterprises. Increasing salt business and productivity can be increased through cooperatives. Sustainability from an institutional perspective can be achieved by improving the human resources quality in managing the salt business, drafting regulations on the sale and purchase of salts, and technology training for salt farmers (Subhan et al., 2021). Furthermore, increasing sustainability with the capacity of human resources and services of financial institutions can be performed to compete at the local and the regional levels of salt industries. (Diananing et al., 2021). The existence of a salt cooperative is an important indicator in the sustainability of saltworks integration. Salt Business Group (SBG) is a group of people who have saltworks activities with a minimum number of administrators and members of 10 people. Salt is needed by several small groups to produce it, so that it is economically sustainable (Antonites, 2016). An integrated management is also needed in the feasibility and potential of salt ponds (Rocha et al., 2012). The existence of cooperatives can also increase the sustainability of salt farmers and increase profits with stable salt prices. This is certainly the support of local and central governments (Muhandhis et al., 2019).

\subsection{Monte - Carlo Analysis}

The sustainability of saltworks integration in ecological, technological, economic, social and institutional (ETESI) aspects are conducted using Monte-Carlo analysis (Figure 6). Raci Village - Batangan Subdistrict, Genengmulyo Village - Juwana Subdistrict and Kertomulyo Village - Trangkil Subdistrict showed a little disturbance because the distribution of blue dots was around the initial score. The village of Tluwuk Wedarijaksa Subdistrict showed significant disturbances because the distribution of red dots spreads rather wide around the village.

For the results of Monte-Carlo analysis in the sustainability aspects of saltworks integration sustain- ability, Raci Village - Batangan Subdistrict, Kertomulyo Village - Trangkil Subdistrict showed a little disturbance because the distribution of blue dots was around the initial score. Tluwuk Village - Wedarijaksa Subdistrict and Genengmulyo Village - Juwana Subdistrict showed significant disturbances because the distribution of red dots spreads rather wide around the village. For the results of Monte-Carlo analysis in the economic aspects of saltworks integration sustainability, Raci Village, Batangan District, Kertomulyo Village, Trangkil District, shows a little disturbance because the distribution of blue dots is around the initial score. Tluwuk Village, Wedarijaksa Subdistrict and Genengmulyo Village, Juwana District showed significant disturbances because the distribution of red dots spreads rather wide around the village.

For the results of Monte-Carlo analysis in the social aspects of saltworks integration sustainability, Raci Village - Batangan Subdistrict, Kertomulyo Village - Trangkil Subdistrict showed a little disturbance because the distribution of blue dots was around the initial score. Tluwuk Village - Wedarijaksa Subdistrict and Genengmulyo Village - Juwana Subdistrict showed significant disturbances because the distribution of red dots spreads rather wide around the village. For the results of Monte-Carlo analysis in the institutional aspects of saltworks integration sustainability, Raci Village - Batangan Subdistrict, Kertomulyo Village - Trangkil Subdistrict showed a little disturbance because the distribution of blue dots was around the initial score. Tluwuk Village - Wedarijaksa Subdistrict and Genengmulyo Village - Juwana Subdistrict showed significant disturbances because the distribution of red dots spreads rather wide around the village.

\subsection{Kite (Radar) Diagram of Saltworks Integration Sustainability}

The kite (radar) diagram of the saltworks integration sustainability is drawn (Figure 7), and the sustainability index value is located in 4 (Table 2). Several aspects of the sustainability of saltworks integration are ecological, technological, economic, social, and institutional aspects (Figure 7). Raci Village - Batangan Subdistrict had the highest indicator value from all aspects compared to other villages. Kertomulyo Village - Trangkil Subdistrict was the second highest indicator values, Genengmulyo Village, Juwana Subdistrict was the third highest indicator values and Tluwuk Village Wedarijaksa Subdistrict was the fourth highest indicator values.

The value of the sustainability index obtained based on the assessment of 41 attributes, i.e., ecological 
JIPK. Volume 14 No 1. April 2022 / The sustainability of Saltworks Integration in Pati Regency, Central Java.

Table 2. Sustainability Index Value of the Saltworks Integration for Each Aspect

\begin{tabular}{|l|l|l|l|l|l|l|}
\hline \multirow{2}{*}{ No } & \multirow{2}{*}{ Location } & \multicolumn{5}{|c|}{ Aspect (\%) } \\
\cline { 3 - 7 } & & Ecological & Technological & Economic & Social & Institutional \\
\hline 1 & Raci & 77.79 & 74.36 & 70.65 & 74.54 & 71.04 \\
\hline 2 & Genengmulyo & 65.62 & 57.84 & 69.80 & 66.34 & 70.15 \\
\hline 3 & Tluwuk & 58.24 & 54.36 & 67.74 & 65.62 & 67.50 \\
\hline 4 & Kertomulyo & 72.01 & 74.95 & 71.12 & 74.69 & 71.02 \\
\hline
\end{tabular}

Source: Processed Data, 2020

aspects of 8 (eight) attributes, technological aspects of 7 (seven) attributes, economic aspects of 9 (nine) attributes, social aspects of 7 (seven) attributes, and institutional aspects of 10 (ten) attributes. The multidimensional attribute assessment in the sustainability aspects of the saltworks integration is illustrated in the kite diagram. The results of the analysis showed that the larger kite diagram indicated the higher level of sustainability. The sustainability status of saltworks integration of the 4 (villages) showed that it was quite sustainable and very sustainable. In order to maintain and improve the sustainability status of saltworks integration, it is necessary to manage the attributes of each sustainability aspect.

\section{Conclusion}

The sustainability index analysis of saltworks integration in the ecological aspects showed Raci Village - Batangan Subdistrict with the sustainable status. Genengmulyo Village - Juwana Subdistrict, Tluwuk Village - Wedarijaksa Subdistrict, Kertomulyo Village - Trangkil Subdistrict showed a sufficiently sustainable status by considering the indicators that affect its sustainability. The technological, economic, social and institutional aspects in all villages of saltworks integration had a sufficiently sustainable status. The sustainability index analysis of saltworks integration in the ecological, technological, economic, social and institutional aspects of Raci Village - Batangan Subdistrict achieved the highest indicator values from all aspects compared to other villages. Meanwhile, Kertomulyo Village - Trangkil Subdistrict was the second highest indicator values, Genengmulyo Village, Juwana Subdistrict was the third highest indicator values, and Tluwuk Village - Wedarijaksa Subdistrict had the lowest indicator values. The saltwork integration system process requires training and coaching for salt farmers regarding good and correct methods of salt production and the empowerment of extension workers for salt system integration process activities.

\section{Acknowledgement}

The first author thanks to Doctoral Program of Coastal Resources Management, Faculty of Fisheries and Marine Science, Diponegoro University, Semarang that provide the good facilitation during study.

\section{Authors' Contributions}

All authors have contributed to the final manuscript. The contribution of each author as follow, Sriwati; collected the data, drafted the manuscript and designed the figures. Aziz Nur Bambang, Johanes Hutabarat, Haeruddin and Tri Winarni devised the main conceptual ideas and critical revision of the article. All authors discussed the results and contributed to the final manuscript.

\section{Conflict of Interest}

The authors declare that they have no competing interests.

\section{Funding Information}

This project is implemented from members' independent funds into a research project.

\section{References}

Akinaga, T., Generalis, S. C., Paton, C., Igobo, O. N., \& Davies, P. A. (2018). Brine utilisation for cooling and salt production in wind-driven seawater greenhouses: Design and modelling. Desalination, 426:135-154.

Antonites, A. (2016). The organization of salt production in early first millennium CE South Africa. Journal of Anthropological Archaeology, 44:3142.

Ariyani, A. H. M., Harianto, H., Suharno, S., \& Syaukat, Y. (2020). Impact of application of geoisolator in saltworks business in East Java Province: A 
propensity-score matching approach. International Journal of Progressive Sciences and Technologies, 22(1):40-47.

Auliyah, N \& Latjolai, M. (2019). Kesesuaian lahan tambak garam di Desa Siduwonge Kecamatan Randangan Kabupaten Pohuwato. Gorontalo Fisheries Journal, 2(1):29-36.

Costa, D. F. da S., Rocha, R. de M., Candido, G. A., \& Soares, A. M. V. da M. (2015). Geographical location and solar salt production. Mercator - Revista de Geografia Da UFC, 14(2):91-98.

Diananing, R., Destryana, A., Santosa, R., Puad, N. I. M., \& Melviana, A. C. (2021). The strategy of salt business development: A case study in Sumenep, Indonesia. E3S Web of Conferences, 226:1-9.

Fatmawati, F., \& Kurdi, M. (2020). Beyond salt industries and environment in Sumenep: Effective partnership for people welfare. IOP Conference Series: Earth and Environmental Science, 469:1-7.

Fernandes, R. T. V., Pinto, A. R. M., Fernandes, R. T. V., de Oliveira, J. F., \& Novaes, J. L. C. (2020). An evaluation of the economic viability of environmental offsets in the saltworks industry. Ciência Rural, 50(5):e20180985.

Geng, X., Boufadel, M. C., \& Jackson, N. L. (2016). Evidence of salt accumulation in beach intertidal zone due to evaporation. Scientific Reports, 6:1-5.

González-Alcaraz, M. N., Aránega, B., Conesa, H. M., Delgado, M. J., \& Álvarez-Rogel, J. (2015). Contribution of soil properties to the assessment of a seawater irrigation programme as a management strategy for abandoned solar saltworks. Catena, 126:189-200.

Jiang, B., Wang, D., Shen, X., Chen, J., \& Lin, W. (2019). Effects of sea salt aerosols on precipitation and upper troposphere/lower stratosphere water vapour in tropical cyclone systems. Scientific Reports, $9(1): 1-13$.

Kavanagh, P., \& Pitcher, T. J. (2004). Implementing Microsoft Excel software for rapfish: A technique for the rapid appraisal of fisheries status. Fisheries Centre Research Reports, 12(2). Canada: University of British Columbia.
Kopnina, H. (2017). Working with human nature to achieve sustainability: Exploring constraints and opportunities. Journal of Cleaner Production, 148:751-759.

Kurniawan, A., Imam Syafi'i, M., Ardian, G., Jaziri, A. A., Amin, A. A., Budiyanto, B., Amenan, M., Ni'matus Salamah, L., \& Budi Setiawan, W. (2019). Continuously dynamic mixing (CDM) method and greenhouse salt tunnel (GST) technology for sea salt production throughout the year. Jurnal Ilmiah Perikanan dan Kelautan, 11(2):8291.

Kurniawan, T., \& Zulham, A. (2020). Salt farmer's adaptation strategy facing climate change (case study in Pati Regency). IOP Conference Series: Earth and Environmental Science, 521:1-9.

Ladhar, C., Tastard, E., Casse, N., Denis, F., \& Ayadi, H. (2015). Strong and stable environmental structuring of the zooplankton communities in interconnected salt ponds. Hydrobiologia, 743:1-13.

Liyanaarachchi, S., Shu, L., Muthukumaran, S., Jegatheesan, V., \& Baskaran, K. (2014). Problems in seawater industrial desalination processes and potential sustainable solutions: A review. Reviews in Environmental Science and Bio/Technology, 13:203-214.

Ministry of Marine Affairs and Fisheries. (2020). Petunjuk teknis pengembangan usaha garam rakyat (PUGAR). (pp. 176). Jakarta: Ministry of Marine Affairs and Fisheries.

Misyura, S. Y. (2020). The crystallization behavior of the aqueous solution of $\mathrm{CaCl}_{2}$ salt in a drop and a layer. Scientific Reports, 10(1):1-10.

Muhandhis, I., Susanto, H., \& Asfari, U. (2019). Development of system dynamics model to increase salt fulfillment ratio. Procedia Computer Science, 161:867-875.

Muhandhis, I., Wirjodirdjo, B., Suryani, E., \& Susanto, H. (2021). Modeling of salt supply chains to achieve competitive salt prices. International Journal on Food System Dynamic, 12(1):51-67.

Nariyoshi, Y. N., Pantoja, C. E., \& Seckler, M. M. (2016). Evaluation of sodium chloride crystalli- 
zation in membrane distillation crystallization applied to water desalination. Brazilian Journal of Chemical Engineering, 33(3):655-690.

Nayar, K. G., Fernandes, J., McGovern, R. K., Dominguez, K. P., McCance, A., Al-Anzi, B. S., \& Lienhard, J. H. (2019). Cost and energy requirements of hybrid RO and ED brine concentration systems for salt production. Desalination, 456:97-120.

Nguyen, P. V., Huang, C. T., Truong, K. H., \& Hsiao, Y. J. (2020). Profitability improvement for brine shrimp Artemia franciscana commercial farming in coastal saltworks in the Mekong Delta, Vietnam: A bioeconomic analysis. Journal of the World Aquaculture Society, 51(4):896-917.

Nhung, T. T., Vo, P. L., Nghi, V. V., \& Bang, H. Q. (2019). Salt intrusion adaptation measures for sustainable agricultural development under climate change effects: A case of Ca Mau Peninsula, Vietnam. Climate Risk Management, 23:88-100.

Panagopoulos, A. (2020). Techno-economic evaluation of a solar multi-effect distillation/thermal vapor compression hybrid system for brine treatment and salt recovery. Chemical Engineering and Processing - Process Intensification, 152:107934.

Patel, J., Markam, B. K., \& Maiti, S. (2019). Potable water by solar thermal distillation in solar salt works and performance enhancement by integrating with evacuated tubes. Solar Energy, 188:561572.

Rodrigues, C. M., Bio, A., Amat, F., Vieira, N. (2011). Artisanal salt production in Aveiro/Portugal-An ecofriendly process. Saline Systems, 7(3):1-14.

Rocha, R. de M., Costa, D. F. da S., Filho, M. A. L., Bezerra, R. M., Medeiros, D. H., Silva, A. M. A., Araújo, C. N., \& Filho, L. X. (2012). Brazilian solar saltworks - ancient uses and future possibilities. Aquatic Biosystem, 8:8.
Rochwulaningsih, Y. (2018). Salt production business potential in Aceh as Capital for the Coastal Communities Welfare. Journal of Maritime Studies and National Integration, 2(1):23-30.

Sainz-López, N. (2017). Comparative analysis of traditional solar saltworks and other economic activities in a Portuguese Protected Estuary. Boletín de Investigaciones Marinas y Costeras - INVEMAR, 46(1):171-189.

Soares, R. H. R. de M., de Assunção, C. A., Fernandes, F. de O., \& Marinho-Soriano, E. (2018). Identification and analysis of ecosystem services associated with biodiversity of saltworks. Ocean \& Coastal Management, 163:278-284.

Sparenberg, M. C., Ruiz Salmón, I., \& Luis, P. (2020). Economic evaluation of salt recovery from wastewater via membrane distillation-crystallization. Separation and Purification Technology, 235: 116075.

Subhan, M., Anggeni, P., \& Hayati, S. (2021). Salt marketing strategy in East Lombok Regency, West Nusa Tenggara. Journal of Aquaculture and Fish Health, 10(1):95-100.

Sudaryana, B., \& Pramesti, P. (2018). The strategy of welfare improvement for salt farmers in Indonesia. Matec Web of Conferences, 150:1-7.

Suhendi, S., Abdullah, A., \& Shalihati, F. (2020). The effectiveness of the salt policy in Indonesia. Jurnal Manajemen dan Agribisnis, 17(3):315-324.

Vieira, N., \& Bio, A. (2011). Spatial and temporal variability of water quality and zooplankton in an artisanal salina. Journal of Sea Research, 65(2):293303.

Zhang, L., Zhang, Y., Hao, X., Ma, L., \& Gao, C. (2021). Preparation of deep-sea refined salt by solution crystallization technology. IOP Conference Series: Earth and Environmental Science, 804:1-4. 